\title{
PEMILIHAN DAN PENGGUNAAN BAHASA ARAB OLEH MAHASISWA UNIVERSITAS CANAL SUEZ MESIR
}

\author{
Ghita Lusiana Dewi \\ ghitalusiana1213@gmail.com \\ Muhammad Ridwan \\ muhammadridwan_fib@staff.uns.ac.id \\ Program Studi Sastra Arab Fakultas Ilmu Budaya \\ Universitas Sebelas Maret Seurakarta
}

\begin{abstract}
This research aims to describe students preference and the use of Arabic language at the academia, social interactions and media. The data were taken from 24 respondents who are still studying in Suez Canal University in Egypt. The main instrument used in this research named Discourse Completion Test (DCT), in the form of three questionnaires distributed randomly to the selected students as the sample. This research used indirect method with Likert scale to measure the language attitude. The preference and the use of Arabic by students in the field of academic, social interaction, and the media showed a varying result. In field of academic and media, students tend to choose and use BAF, while in the field of social interactions students tend to choose and use BAA. The departments that have the highest percentage on the election and use of the Arabic in the academic are Math, Chemistry, Hospitality, Arabic, and History. Then, in the social interaction field, the percentage of preference and use of BAA by male students is higher than women. These results indicate that departments and gender had a role in the preference and use of the Arabic by students.
\end{abstract}

Keywords: Language Attitude, Egypt, Standard Arabic, Egyptian Arabic

$$
\begin{aligned}
& \text { ملخص البحث } \\
& \text { يههدف هذا الحثث الم كشف وصف اختيار واستخدام اللغة العربية في المجال الأكاديمي والتفاعل الاجتماعي ماتحي } \\
& \text { ووسائل الإعلام. تُؤخذ بيانات هذا البحث من 24 24جيبا من الطلاب الذين يتعلمون في جامعة قناة السويس في } \\
& \text { مصر. أما الوسيلة المستخدمة في هذا البحث هي Discourse Completion Test (DCT) } \\
& \text { ثلاثة انماط الاستبيان إلى الطلاب و المحددة كعينات تبقنيات العينات العشوائية. الأسلوب المستخدم يعني }
\end{aligned}
$$

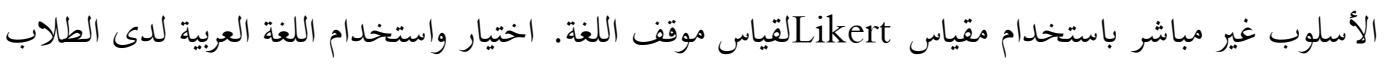

$$
\begin{aligned}
& \text { في المجال الأكاديمي والتفاعل الاجتماعي ووسائل الإعلام أظهر النتائج المتنوّعة. في المجال الأكاديمي ووسائل } \\
& \text { الإعلام يميل الطلاب لاختيار واستخدام اللغة العربية الفصحى و في مجال التفاعل الاجتماعي يميل الطلاب لئل }
\end{aligned}
$$




$$
\begin{aligned}
& \text { لاختيار واستخدام اللغة العربية العامية. القسم الذي لديه أعلى نسبة في اختيار واستخدام اللغة العربية في المجال }
\end{aligned}
$$

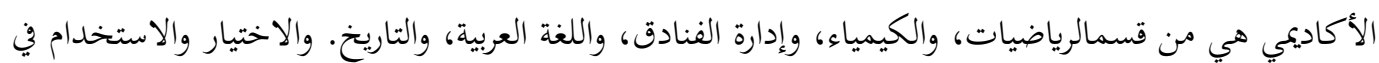

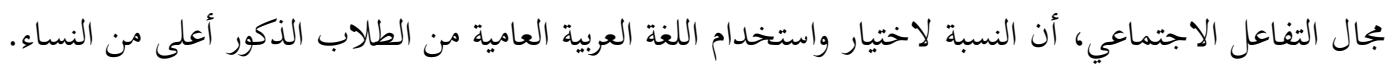

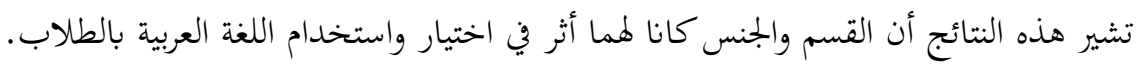

$$
\begin{aligned}
& \text { الكلمات الرئيسية: مواقف اللغة ومصر واللغة العربية الفصحواللغة العربية العامية }
\end{aligned}
$$

\section{A. Pendahuluan}

Mesir merupakan salah satu negara di Timur Tengah yang memiliki dua varian bahasa yang saling berdampingan atau sering disebut dengan diglosia. Menurut Ferguson dalam masyarakat diglosis terdapat dua variasi dari satu bahasa yaitu variasi pertama yang disebut dengan dialek tinggi dan yang kedua disebut dengan dialek rendah (Chaer dan Agustina, 2008: 93). Murad (2007: 19) menambahkan bahwa biasanya salah satuvarietas standar, bergengsi, dan formal; sementara yang lain adalah gaul, sehari-hari ataudialek.

Dialek tinggi atau bahasa formal yang ada di Mesir disebut dengan bahasa Arab Fuscha (BAF) sedangkan dialek rendah yang ada di Mesir disebut dengan bahasa Arab Amiyah (BAA).BAF atau bahasa Arab Standar disebut sebagai bahasa persatuan, bahasa resmi dan bahasa baku di dunia Arab. Namun, penggunaannya dalam kehidupan sehari-hari semakin jarang. MasyarakatArab cenderung lebih banyak menggunakan BAA atau bahasa nonbaku dibandingkan BAF. Hal ini karena masyarakat menganggap BAF tidak luwes dan kurang bersahabat dengan anak-anak (Tohe, 2005: 209). Seperti yang diungkapkan Farihah (dalam Tohe, 2005: 209) bahwa dalam suasana resmi masyarakat Arab menggunakan BAF, sedang dalam kehidupan sehari-hari mereka menggunakan BAA.

Variasi dan sikap terhadap bahasa Arab merupakan pembahasan yang menarik dan telah menerima perhatian khusus dalam kajian psikologi sosial dan sosiolinguistik terutama pada pertengahan abad ke-20. Variasi ini juga menarik batas identitas suatu masyarakat, misalnya orang Mesir berbicara dengan bahasa Arab Mesir, orang Irak berbicara dengan bahasa Arab Irak (Murad, 2007: 16).

Murad (2007: 17)juga mengatakan bahwa banyak orang Arab menganggap bahwa bahasa Arab Standar sebagai penanda identitas orang Arab. Oleh karena itu, ada keyakinan kuat bahwa seseorang yang berbicara bahasa Arab (standar) ialah orang Arab. Sebagai hasilnya, bahasa Arab memiliki arti penting bagi orang Arab. Hal ini telah menjadi faktor penting yang mewakili patriotisme, kekuatan, dan nasionalisme di dunia Arab.

Bahasa Arab menjadi bahasa alQur'an, mempertahankan status yang unik dan luar biasa, yang ditandai dengan hormat, kekaguman, dan apresiasi. Fenomena linguistik yang ada di dunia Arab adalah koeksistensi bahasa Arab Standar (fuschā) bersama dengan dialek nasional yang dalam bahasa Arab disebut dengan 'ämiyah.

Biasanya, salah satu dari kedua varian bahasa tersebut adalah varietas 
standar, bergengsi, dan formal; sementara yang lain adalah bahasa gaul, bahasa sehari-hari ataudialek. Dalam dunia berbahasa Arab, bahasa Arab Standar digunakan dalam berbagai domain sepertimedia cetak, pendidikan, ritual keagamaan, dan pengaturan formal. Dialek Arab, padasisi lain, digunakan secara ekstensif dalam sehari-hari dengan tujuan mencapai tujuan komunikasi. Sebagian besar dari penutur Arab sangat memuja bahasa Arab Standarkarena bahasa Arab Standarberhubungan denganpengetahuan, agama, dan inspirasi. Dialek, di sisi lain, dipandang sebagaibentuk terdistorsi rendah dan tidak berpendidikan Arab (Haeri dalam Murad, 2007: 19). Dialek dipandang sebagai suatu penyimpangan dari bahasa Arab Standar dan biasanya lebih banyak digunakan oleh masyarakat yang memiliki pendidikan rendah dalam berkomunikasi.

Begitu pula yang terjadi pada mahasiswa di Mesir, mereka cenderung lebih memilih untuk menggunakan BAA dalam kehidupan sehari-hari dibandingkan BAF. Meskipun mahasiswa memiliki kemahiran dalam BAF namun mereka lebih memilih menggunakan BAA untuk berkomunikasi, baik di lingkungan kampus untuk berkomunikasi dengan teman-teman dan dosennya maupun di lingkungan rumah.Berdasarkan latar belakang di atas, penelitian ini mengkaji tentang pemilihan dan penggunaan bahasa Arab oleh mahasiswa Universitas Canal Suez Mesir.

Mizher dan Al-Haq (2014) dalam penelitiannya yang berjudul Attitudes towards Using Standard Arabic among Academic Staff at Balqa Applied
University/Center in Jordan: A Sociolinguistic Study menunjukkan bahwa sikap para staf akademik Universitas Balqa Yordania terhadap bahasa Arab Standar adalah tinggi, baik sebagai bahasa pengantar maupun pertemuan sosial mereka. Sikap ini mencerminkan status arabicizationyang merupakan bagian dari perencanaan bahasa dari lembaga pendidikan tinggi di Yordania dalam persaingan antara kelompok proarabicization dan kelompok antiarabicization. Responden merupakan staf akademik yang berasal dari empat fakultas, yakni fakultas Teknik, Pertanian, Humaniora, dan fakultas Perencanaan. Hasil penelitian ini juga menegaskan adanya semangat untuk bebicara bahasa Arab Standar sebagai bahasa tinggi. Responden mendorong penggunaan bahasa Arab Standar dalam konteks akademik pada umumnya dan pertemuan yang diadakan di tingkat lokal dan nasional. Bahasa Arab Standar juga disukai oleh kalanganakademis Arab dalam berbagai interaksi.

Murad (2007) dalam penelitiannya yang berjudul Language Attitudes of Iraqi Native Speakers of Arabic: A Sociolinguistic Investigation menunjukkan bahwa terdapat perbedaan sikap yang signifikan antara mahasiswa dan non mahasiswa terhadap bahasa Arab Standar dan bahasa Arab Irak. Mahasiswa lebih bersikap positif terhadap bahasa Arab Standar dibandingkan bahasa Arab Irak, namun sebaliknya orang Irak nonmahasiswa lebih banyak memilih menggunakan bahasa Arab Irak dibandingkan bahasa Arab Standar. Hal ini berarti sikap bahasa orang Irak nonmahasiswa lebih negatif dibandingkan mahasiswa di Irak. 
Faktor yang paling memengaruhi munculnya sikap ini adalah level pendidikan berbeda, sehingga pandangan dan penggunaan variasi bahasa juga sangat berbeda.

Menurut Ciscel, dkk. (2000:49) sikap bahasa adalah "value terhadap suatu bahasa baik dalam konteks sosio-personal maupun sosioekonomi" yang terbentuk melalui interaksi dalam suatu komunitas bahasa. Sikap bahasa ditekankan pada kesadaran diri sendiri dalam menggunakan bahasa secara tertib (Pateda, 1990: 30).Konteks sosiopersonal yang dimaksud adalah bahasa yang terkait dengan sentimental attachment yakni bahasa dikaitkan dengan daya tarik personal seperti identitas diri maupun identitas bangsa dan juga sebagai warisan budaya sedangkan sosio-ekonomi terkait dengan instrumental attachment yakni bahasa dijadikan sarana untuk mendapatkan beragam kemudahan seperti misalnya kemudahan mendapatkan pekerjaan (karena menguasai bahasa tertentu) sehingga berimbas pada tingkatan ekonominya (Eastman dalam Wulandari dan Wiwiek, 2012).

Sikap bisa positif dan bisa juga negatif, maka sikap terhadap bahasapun demikian. Garvin dan Mathiot (dalam Chaer dan Agustina, 2008: 152) menyebutkan ciri-ciri sikap positif terhadap bahasa, yaitu:

a. Kesetiaan bahasa (language loyalty) yang mendorong masyarakat suatu bahasa mempertahankan bahasanya dan apabila perlu mencegah adanya pengaruh bahasa lain.

b. Kebanggaan bahasa (language pride) yang mendorong orang mengembangkan bahasanya dan menggunakannya sebagai lambang identitas dan kesatuan masyarakat.

c. Kesadaran adanya norma bahasa (awareness of the norm) yang mendorong orang menggunakan bahasanya dengan cermat dan santun

\section{B. Metodologi Penelitian}

Populasi penelitian ini adalah semua mahasiswa Universitas Canal Suez Mesir yang masih aktif atau masih menjalankan studi di Universitas Canal Suez Mesir. Kemudian sampel pada penelitian ini adalah 24 mahasiswa yang merupakan bagian atau menjadi perwakilan dari populasi tersebut.

Semua responden diminta untuk mengisi Discourse Completion Test (DCT) (Blum-Kulka, 1982). Tes ini telah banyak digunakansejak saat itudalam mengumpulkandata (AlMarani dan Sazalle, 2010: 67). DCT pada penelitian ini berupa kuesioner yang memodifikasi dari penelitian sebelumnya Murad (2007).

Penelitian ini menggunakan metode tidak langsung (indirect measure of attitudes). Metode tidak langsung digunakan untuk memancing jawaban responden sementara dirinya tidak menyadar bahwa sikapnya sedang diteliti. Kemudian, teknik yang digunakan (Fasold, 2001: 149) adalah teknik kuesioner, yakni dilakukan dengan cara memberikan daftar pertanyaan berupa pertanyaan tertutup. Dalam pertanyaan tertutup terdapat kemungkinan jawaban yang telah ditentukan. Mereka diminta menjawab pertanyaan dengan cara memilih jawaban yang terdapat di dalam daftar (Rokhman, 2013: 46-47). 
Kuesioner berisi 15 (lima belas) pernyataan mengenai sikap bahasa yang disebarkan secara acak kepada 24 (dua puluh empat) responden.Responden merupakan mahasiswa Universitas Canal Suez Mesir yang terdiri dari 12 (dua belas) mahasiswa laki-laki dan 12 (dua belas) mahasiswa perempuan.

\section{Pembahasan}

Menurut Ferguson dalam masyarakat diglosis terdapat dua variasi dari satu bahasa yaitu variasi pertama disebut dengan dialek tinggi dan yang kedua disebut dengan dialek rendah (Chaer dan Agustina, 2008: 93). Bahasa Arab Fuscha>(BAF) merupakan dialek tinggi dan bahasa Arab 'A>miyah (BAA) merupakan dialek rendah.

Pemilihan bahasa berhubungan dengan dua varian bahasa atau lebih yang dimiliki sebuah negara dan penutur bahasa harus memilih salah satu bahasa harus digunakan (Chaer dan Agustina, 2008: 153). Pemilihan dan penggunaan bahasa berhubungan erat dengan dinamisnya masyarakat bahasa dalam berbagai kegiatan dan kelompok. Seperti halnya mahasiswa yang banyak melakukan kegiatan baik di lingkungan sosial sebagai bagian dari masyarakat, maupun di lingkungan universitas sebagai mahasiswa dan bagian dari kelompok atau komunitas yang diikutinya.

Ranah-ranah pemilihan dan penggunaan BAF dan BAA oleh mahasiswa Universitas Canal Suez Mesir yaitu lingkungan akademik (academia), interaksi sosial, dan media. Pada ranah itulah mahasiswa banyak berkontribusi di dalamnya dan berinteraksi dengan lingkungan disekitarnya baik di lingkungan universitas maupun sosial.
1. Pemilihan dan Penggunaan Bahasa Arab di Lingkungan Akademik

Di lingkungan akademik banyak sekali kegiatan-kegiatan yang dilakukan, seperti perkuliahan, diskusi, bimbingan, ujian, penelitian, dan seminar yang semua kegiatan tersebut diperlukan komunikasi. Komunikasi dapat dilakukan melalui bahasa; baik secara lisan maupun tulisan.

Universitas sebagai lingkungan akademik mahasiswa memberikan pengaruh terhadap pemilihan dan penggunaan bahasa Arab mahasiswa. Tidak jarang mahasiswa lebih menggunakan BAA sebagai bahasa yang mereka gunakan dibandingkan BAF, bahkan ketika berkomunikasi dengan dosen.

Pemilihan dan penggunaan bahasa Arab di lingkungan akademik ini juga dilihat dari pengaruh program studi yang mereka tempuh di Universitas Canal Suez Mesir. Dari berbagai program studi yang dipilih ternyata terdapat perbedaan dalam pemilihan dan penggunaan bahasa Arab mahasiswa.

Di bawah ini terdapat beberapa situasi yang dihadirkan dan persentase pemilihan dan penggunaan BAF dan BAA oleh mahasiswa Universitas Canal Suez Mesir di lingkungan akademik.

a. Pemilihan BAF dan BAA di Lingkungan Akademik

Pemilihan BAF dan BAA di lingkungan akademik terlihat sangat kontras (lihat tabel 1). Pemilihan BAF di lingkungan akademik lebih tinggi dibandingkan BAA. Persentase ratarata pemilihan $\mathrm{BAF}$ adalah $75.0 \%$, sedangkan persentase rata-rata pemilihan BAA adalah $25.0 \%$. 


\begin{tabular}{|c|c|c|c|c|c|}
\hline \multirow{2}{*}{ No. } & \multirow{2}{*}{ Situasi } & \multicolumn{2}{|c|}{ BAF } & \multicolumn{2}{|c|}{ BAA } \\
\hline & & $\mathbf{f}$ & $\%$ & f & $\%$ \\
\hline 1 & 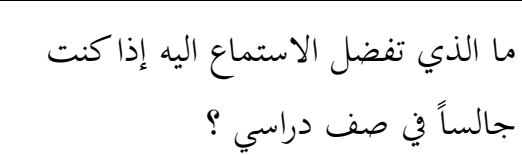 & 37 & $74.0 \%$ & 13 & $26.0 \%$ \\
\hline 2 & 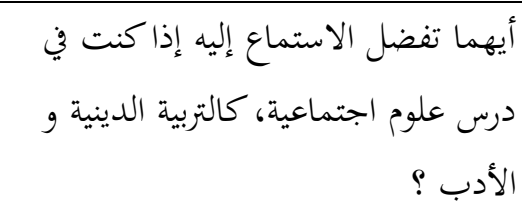 & 41 & $82.0 \%$ & 9 & $18.0 \%$ \\
\hline 3 & أيهما تفضل الاستماع اليه إذا كنت & 31 & $62.0 \%$ & 19 & $38.0 \%$ \\
\hline 4 & 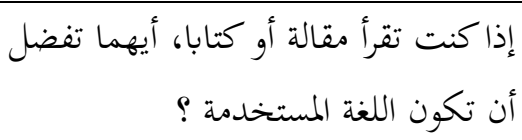 & 41 & $82.0 \%$ & 9 & $18.0 \%$ \\
\hline & Rata-rata & & $75.0 \%$ & & $25.0 \%$ \\
\hline
\end{tabular}

Tabel 1. Pemilihan BAF dan BAA di Lingkungan Akademik

Mayoritas mahasiswa Universitas Canal Suez Mesir memilih BAF dibandingkan BAA ketika mereka berada di dalam kelas (situasi 1). Alasan $74.0 \%$ mahasiswa memilih BAF ketika di dalam kelas karena BAF adalah bahasa yang sangat bagus/indah $(r a>i$ 'ah), bahasa al-Qur'an, dan bahasa yang terjaga keasliannya. Mahasiswa juga banyak menggunakan BAF ketika berada di kelas pengetahuan sosial seperti pendidikan agama dan sastra (situasi 2), dengan persentase sebanyak $82.0 \%$. Alasan pemilihan BAF ketika pada situasi 2 juga sama seperti pada situasi 1 , yakni karena BAF adalah bahasa yang digunakan di dalam al-Qur'an dan bahasa yang tinggi serta terjaga, sehingga ketika pada mata kuliah keagamaan dan kesusastraan, mahasiswa lebih memilih BAF dibandingkan BAA. Persentase BAF juga tinggi pada situasi 4 yakni pemilihan bahasa mahasiswa ketika membaca sebuah artikel atau buku, yakni mencapai $82.0 \%$. Hal ini dilihat bahwa artikel dan buku adalah karya tulis ilmiah sehingga mayoritas mahasiswa memilih membaca artikel dan buku dengan BAF dibandingkan dengan BAA.

Namun, persentase pemilihan BAF tersebut lebih kecil ketika mahasiswa memilih BAF di dalam kelas eksak seperti fisika dan kedokteran (situasi 3 ), yakni $62.0 \%$. Hal ini berarti mata kuliah yang diikuti memengaruhi pemilihan BAF dan juga BAA di lingkungan akademik. Mata kuliah yang bersifat kontemporer seperti pada situasi 3 lebih dipahami ketika menggunakan BAA daripada menggunakan BAF.

Pemilihan BAA pada ranah akademik lebih kecil dibandingkan BAF. Mahasiswa yang memilih BAA berasumsi bahwa penyampaian dengan 
BAA di dalam kelas baik pada mata kuliah yang bersifat sosial maupun eksak lebih mudah dipahami daripada BAF.

Pemilihan program studi mahasiswa di Universitas Canal Suez
Mesir ternyata juga memengaruhi pemilihan bahasa mereka. Berikut hasil pemilihan BAF dan BAA berdasarkan program studi yang mereka tempuh.

\begin{tabular}{|l|l|l|l|}
\hline No. & \multicolumn{1}{|c|}{ Program Studi } & \multicolumn{1}{c|}{ BAF } & \multicolumn{1}{c|}{ BAA } \\
\hline 1. & Bahasa Arab & $92.6 \%$ & $7.4 \%$ \\
\hline 2. & Bahasa Inggris & $31.3 \%$ & $68.8 \%$ \\
\hline 3. & Geografi & $41.7 \%$ & $58.3 \%$ \\
\hline 4. & Kimia & $100.0 \%$ & $0.0 \%$ \\
\hline 5. & Perhotelan & $100.0 \%$ & $0.0 \%$ \\
\hline 6. & Sejarah & $80.0 \%$ & $20.0 \%$ \\
\hline 7. & Matematika & $100.0 \%$ & $0.0 \%$ \\
\hline 8. & Psikologi & $43.8 \%$ & $56.3 \%$ \\
\hline 9. & Perniagaan/ Bisnis & $25.0 \%$ & $75.0 \%$ \\
\hline
\end{tabular}

Tabel 2. Pemilihan BAF dan BAA berdasarkan Program Studi

Dapat dilihat pada tabel 2 bahwa pemilihan BAF terbanyak berdasarkan program studi adalah program studi Matematika, Kimia, Perhotelan, Bahasa
Arab, dan Sejarah. Persentase keempat program studi tersebut dalam pemilihan $\mathrm{BAF} \geq 80.0 \%$. Hal tersebut juga dapat terlihat pada diagram di bawah ini :

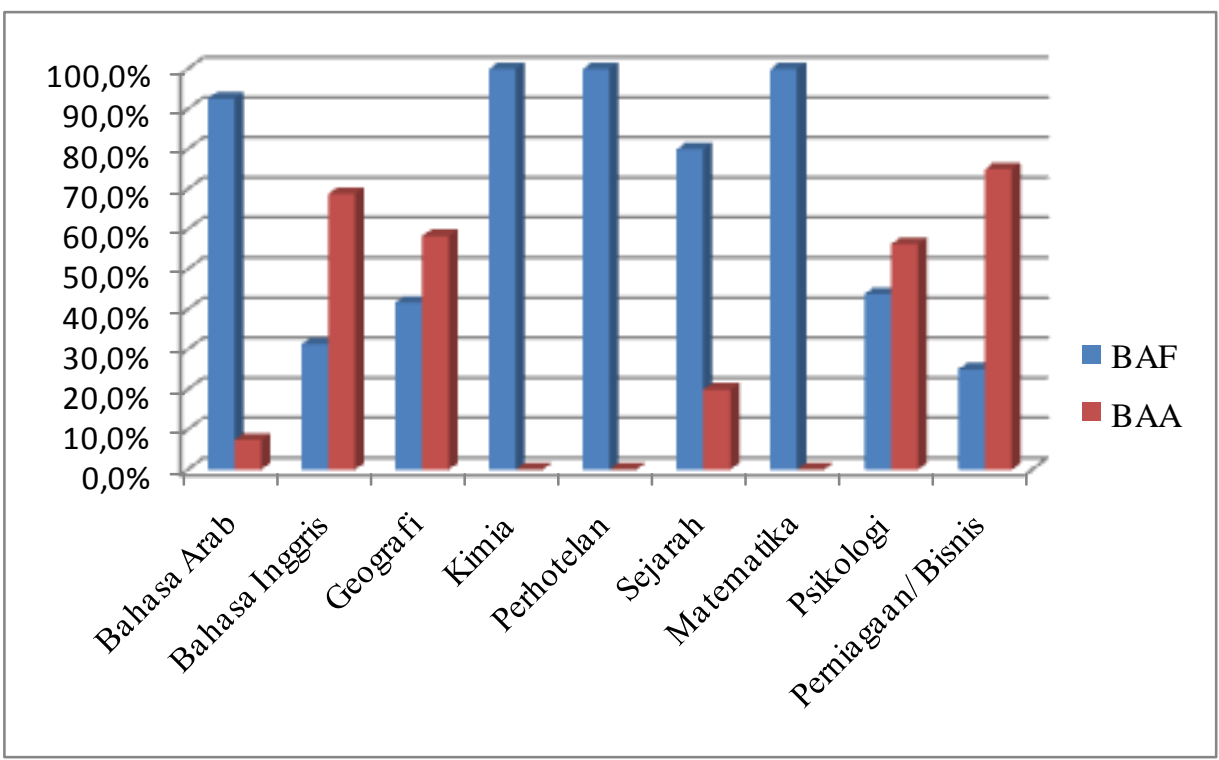

Diagram 1. Pemilihan BAF dan BAA berdasarkan Program Studi

Pada grafik tersebut juga terlihat Berdasarkan tabel dan diagram bahwa program studi Bahasa Inggris, pemilihan bahasa Arab yang Geografi, Psikologi dan Perniagaan/ ditampilkan, dapat dilihat bahwa Bisnis lebih memilih BAA pemilihan bahasa Arab di lingkungan dibandingkan BAF. Akademik lebih banyak pada BAF 
dibandingkan BAA. Program studi yang dipilih mahasiswa juga memengaruhi pemilihan bahasa mereka. Program studi Bahasa Arab yang setiap harinya berhubungan langsung dengan kajian bahasa Arab juga memengaruhi pemilihan bahasa Arab mahasiswanya.

b. Penggunaan BAF dan BAA di Lingkungan Akademik
Rata-rata persentase penggunaan BAF dan BAA sedikit berbeda dengan pemilihan BAF dan BAA di lingkungan akademik. Meskipun demikian, rata-rata persentase tersebut tetap menunjukkan bahwa mayoritas mahasiswa Universitas Canal Suez Mesir lebih banyak menggunakan BAF dibandingkan BAA, dengan rata-rata persentase penggunaan $\mathrm{BAF}$ sebanyak $70.0 \%$ dan BAA sebanyak $30.0 \%$.

\begin{tabular}{|c|c|c|c|c|c|}
\hline \multirow{2}{*}{ No. } & \multirow{2}{*}{ Situasi } & \multicolumn{2}{|c|}{ BAF } & \multicolumn{2}{|c|}{ BAA } \\
\hline & & f & $\%$ & $\mathbf{f}$ & $\%$ \\
\hline 1 & إذا كنت جالساً في صف دراسي، ماذا & 32 & $64.0 \%$ & 18 & $36.0 \%$ \\
\hline 2 & إذاكنت في درس علوم اجتماعية كالتربية & 39 & $78.0 \%$ & 11 & $22.0 \%$ \\
\hline 3 & ماذا إذنت في درس علمي كالفيزياء والطب، & 27 & $54.0 \%$ & 23 & $46.0 \%$ \\
\hline 4 & ماذا تستخدم إذا أردت أن تكتب مقالة أو & 42 & $84.0 \%$ & 8 & $16.0 \%$ \\
\hline & Rata-rata & & $70.0 \%$ & & $30.0 \%$ \\
\hline
\end{tabular}

Tabel 3. Penggunaan BAF dan BAA di Lingkungan Akademik

Pada situasi 1 yakni penggunaan bahasa Arab di dalam kelas, mayoritas mahasiswa menggunakan BAF dengan persentase $64.0 \%$. Namun, alasan penggunaan BAF pada situasi ini tidak banyak yang mencantumkan, sehingga mahasiswa dianggap memiliki alasan yang sama dengan pemilihan BAF pada situasi 1. Begitu pula pada situasi 2, mahasiswa banyak menggunakan BAF ketika berada di kelas pengetahuan sosial seperti pendidikan agama dan sastra, dengan persentase sebanyak $78.0 \%$. Kemudian penggunaan $\mathrm{BAF}$ ketika membaca artikel dan buku juga tinggi dengan persentase $84.0 \%$.

Penggunaan bahasa pada situasi 3 yakni penggunaan bahasa ketika berada pada kelas eksak, seperti fisika dan kedokteran, memiliki persentase yang hampir sama. Penggunaan BAF pada situasi ini sebesar $54.0 \%$, sedangkan penggunaan BAA sebesar $46.0 \%$. Penggunaan BAA pada situasi ini berarti memiliki persentase lebih besar dibandingkan persentase pemilihan BAA.

Adapun pengaruh program studi terhadap penggunaan bahasa Arab di lingkungan akademik terlihat seperti 
pada pemilihan bahasa Arab. Program studi yang memiliki persentase tertinggi diatas $80.0 \%$ adalah
Matematika, Kimia, Bahasa Arab, dan Sejarah. Seperti yang terlihat pada tabel berikut.

\begin{tabular}{|l|l|l|l|}
\hline No. & \multicolumn{1}{|c|}{ Program Studi } & \multicolumn{1}{c|}{ BAF } & \multicolumn{1}{c|}{ BAA } \\
\hline 1. & Bahasa Arab & $84.3 \%$ & $15.7 \%$ \\
\hline 2. & Bahasa Inggris & $56.3 \%$ & $43.8 \%$ \\
\hline 3. & Geografi & $58.3 \%$ & $41.7 \%$ \\
\hline 4. & Kimia & $100.0 \%$ & $0.0 \%$ \\
\hline 5. & Perhotelan & $0.0 \%$ & $100.0 \%$ \\
\hline 6. & Sejarah & $80.0 \%$ & $20.0 \%$ \\
\hline 7. & Matematika & $100.0 \%$ & $0.0 \%$ \\
\hline 8. & Psikologi & $37.5 \%$ & $62.5 \%$ \\
\hline 9. & Perniagaan/ Bisnis & $0.0 \%$ & $100.0 \%$ \\
\hline
\end{tabular}

Tabel 4. Penggunaan BAF dan BAA berdasarkan Program Studi

Peringkat penggunaan BAF dan dapat dilihat pada diagram di bawah ini BAA berdasarkan program studi juga :

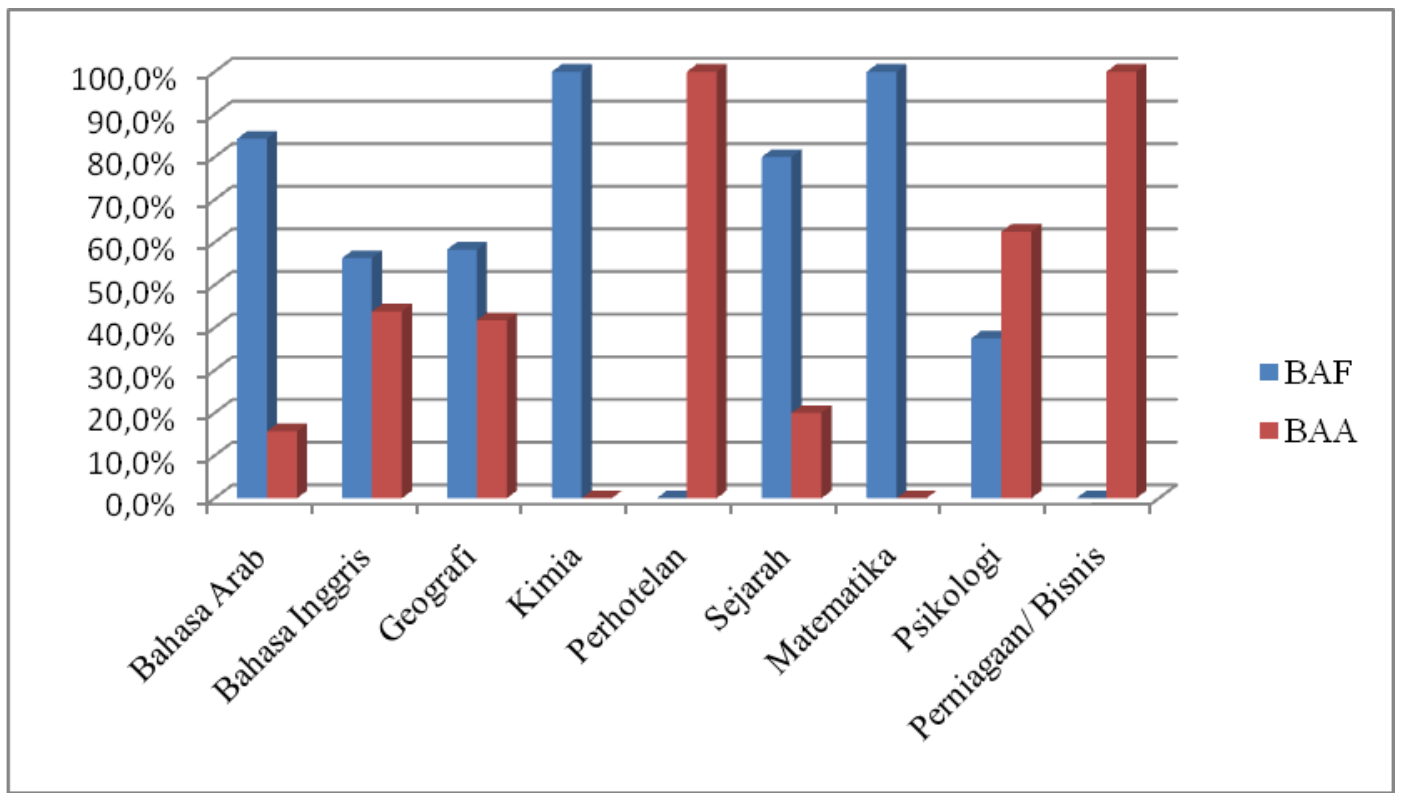

Diagram 2. Penggunaan BAF dan BAA berdasarkan Program Studi

Berdasarkan penjabaran hasil di atas, maka dapat disimpulkan bahwa pemilihan dan penggunaan bahasa Arab dilingkungan akademik mahasiswa Universitas Canal Suez Mesir lebih banyak memilih dan menggunakan BAF dibandingkan BAA, dengan rata-rata pemilihan dan penggunaan BAF dan BAA yang telah disebutkan. Program studi yang dipilih oleh mahasiswa ternyata juga memengaruhi pemilihan dan penggunaan BAF dan BAA di lingkungan akademik. Program studi yang memiliki presentase tinggi pada pemilihan dan penggunaan BAF adalah 
program studi Matematika, Kimia, Bahasa Arab, dan Sejarah.

2. Pemilihan dan Penggunaan Bahasa Arab dalam Interaksi Sosial

Interaksi sosial merupakan hubungan sosial yang dinamis dan bersifat timbal balik antarindividu maupun antarkelompok. Interaksi sosial merupakan ranah mahasiswa yang sangat luas selain di lingkungan akademik. Mahasiswa banyak melakukan interaksi sosial dengan masyarakat. Oleh karena itu, untuk melakukan interaksi tersebut, mahasiswa memerlukan bahasa sebagai alat berkomunikasi.

Interaksi sosial juga memengaruhi dalam pemilihan dan penggunaan bahasa Arab mahasiswa. Pada interaksi ini, mahasiswa lebih banyak menggunakan BAA dibandingkan BAF.

Untuk memunculkan fenomena tersebut, terdapat beberapa situasi yang dihadirkan dan persentase pemilihan dan penggunaan BAF dan BAA oleh mahasiswa Universitas Canal Suez Mesir dalam interaksi sosial.

\section{a. Pemilihan BAF dan BAA dalam Interaksi Sosial \\ Persentase rata-rata pemilihan} BAF dan BAA dalam interaksi sosial hampir seimbang. Hanya terdapat selisih $0.5 \%$ antara pemilihan BAF dan BAA dalam ranah ini. Persentase rata-rata pemilihan BAA pada ranah ini mencapai $50.5 \%$, sedangkan rata-rata pemilihan BAF mencapai $49.5 \%$.

\begin{tabular}{|c|c|c|c|c|c|}
\hline \multirow{2}{*}{ No. } & \multirow{2}{*}{ Situasi } & \multicolumn{2}{|c|}{ BAF } & \multicolumn{2}{|c|}{ BAA } \\
\hline & & $\mathbf{f}$ & $\%$ & f & $\%$ \\
\hline 1 & $\begin{array}{r}\text { إذا كنت في البيت مع عائلتك، فأيهما } \\
\text { تفضل الاستماع إليه ؟ }\end{array}$ & 10 & $20.0 \%$ & 40 & $80.0 \%$ \\
\hline 2 & $\begin{array}{r}\text { أيهما تفضل الاستماع إليه عند الحديث } \\
\text { الاصدقاء أو الجيران }\end{array}$ & 15 & $30.0 \%$ & 35 & $70.0 \%$ \\
\hline 3 & أيهما تفضل الاستماع إليه في جامعتك ؟ & 30 & $60.0 \%$ & 20 & $40.0 \%$ \\
\hline 4 & دور العهما تفضل أن تكون اللغة المستخدمة في & 44 & $88.0 \%$ & 6 & $12.0 \%$ \\
\hline 5 & ماذا تفضل الاستماع إليه إذا كنت في & 12 & $24.0 \%$ & 38 & $76.0 \%$ \\
\hline 6 & 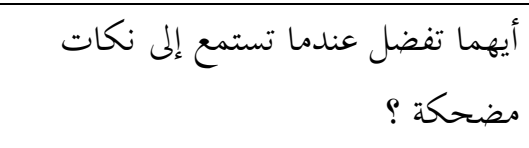 & 3 & $6.0 \%$ & 47 & $94.0 \%$ \\
\hline 7 & أيهما تفضل عندما تستمع إلى قصة ؟ & 39 & $78.0 \%$ & 11 & $22.0 \%$ \\
\hline 8 & تفضل & 45 & $90.0 \%$ & 5 & $10.0 \%$ \\
\hline & Rata-rata & & $49.5 \%$ & & $50.5 \%$ \\
\hline
\end{tabular}

Tabel 5. Pemilihan BAF dan BAA dalam Interaksi Sosial 
Pada situasi 1 dan 2 yakni pemilihan bahasa Arab ketika dirumah bersama keluarga dan pemilihan bahasa Arab ketika berbicara dengan teman atau tetangga menunjukkan persentase yang tinggi pada pemilihan BAA. 80.0 $\%$ memilih BAA pada situasi 1 , dan $70.0 \%$ pada situasi 2. Alasan mahasiswa yang memilih BAA pada kedua situasi tersebut karena BAA adalah bahasa yang mudah digunakan untuk berbicang-bicang/ berbicara, dan BAA adalah bahasa yang simpel (basi>th) dibandingkan BAF. Oleh karena itu, mahasiswa lebih memilih menggunakan BAA dibandingkan BAF.

Selain itu, pada situasi 5 yaitu pemilihan bahasa Arab ketika berada di pasar dan pada situasi 6 yaitu pemilihan bahasa Arab ketika mahasiswa sedang bercanda juga menunjukkan pemilihan bahasa yang tinggi terhadap BAA. Pada kedua situasi tersebut mahasiswa memberikan alasan bahwa terdapat sebagian dari mereka yang tidak dapat berbahasa dengan $\mathrm{BAF}$, sehingga mereka lebih memilih BAA dibandingkan BAF dalam berkomunikasi di pasar dan juga dalam bercanda.

Berbeda dengan itu, pada situasi 3 yaitu pemilihan bahasa Arab ketika berada di unversitas dan situasi 4 yaitu pemilihan bahasa Arab ketika berada di masjid atau tempat peribadatan, mahasiswa lebih memilih BAF sebagai bahasa yang dipilih dibandingkan BAA. Hal tersebut dapat dilihat dengan persentase BAF yang tinggi pada situasi 3 sebanyak $60.0 \%$ dan pada situasi 4 sebanyak $88.0 \%$. Pada situasi 3 , mahasiswa beranggapan bahwa pada situasi kuliah atau berada di universitasakan lebih baik jika memilih menggunakan BAF dibandingkan BAA. Hal ini dikarenakan universitas adalah tempat formal, sehingga harus digunakan pula bahasa yang formal yakni BAF. Kemudian, pada situasi 4, mahasiswa lebih memilih menggunakan BAF dibandingkan BAA ketika berada di masjid atau tempat peribadatan karena BAF adalah bahasa al-Qur'an sehingga untuk menjaga bahasa al-Qur'an, mahasiswa lebih menggunakan BAF dibandingkan BAA.

Persentase pemilihan bahasa Arab ketika bercerita/membacakan sebuah cerita (situasi 7) dan berpuisi/membacakan sebuah puisi (situasi 8) juga menunjukkan persentase yang tinggi pada pemilihan BAF. Persentase untuk BAF pada situasi 7 sebanyak $78.0 \%$, dan persentase pada situasi 8 sebanyak 90.0 $\%$. Alasan mahasiswa memilih BAF pada situasi 7 karena mahasiswa ingin menjaga keindahan pada kisah/cerita tersebut, selain itu sebuah cerita lebih mudah dipahami ketika menggunakan BAF. Kemudian pada situasi 8 mahasiswa berargumentasi bahwa BAF adalah salah satu cara untuk memahami syair/puisi, sehingga puisi lebih mudah dipahami jika menggunakan BAF.

Pada ranah ini, gender ternyata memiliki pengaruh terhadap pemilihan BAF dan BAA meskipun tidak begitu signifikan. Hal tersebut dapat dilihat pada tabel di bawah ini.

\begin{tabular}{|l|l|l|l|}
\hline No. & \multicolumn{1}{|c|}{ Gender } & \multicolumn{1}{c|}{ BAF } & \multicolumn{1}{c|}{ BAA } \\
\hline 1. & Laki-laki/Maskulin & $46.4 \%$ & $\mathbf{5 3 . 6} \%$ \\
\hline 2. & Perempuan/Feminin & $\mathbf{5 0 . 4} \%$ & $49.6 \%$ \\
\hline
\end{tabular}


Tabel 6. Pemilihan BAF dan BAA berdasarkan Gender

Persentase pemilihan BAF laki- perempuan. Perbedaan yang terlihat laki dan perempuan memiliki selisih antara kedua gender ini adalah laki-laki $4.0 \%$, yakni $46.4 \%$ untuk laki-laki, memiliki persentase yang lebih besar dan $50.4 \%$ untuk perempuan. pada pemilihan BAA, sedangkan Kemudian persentase pemilihan BAA perempuan memiliki persentase yang juga memiliki selisih $4.0 \%$, yakni 53.6 lebih besar pada pemilihan BAF (lihat $\%$ untuk laki-laki dan $49.6 \%$ untuk diagram

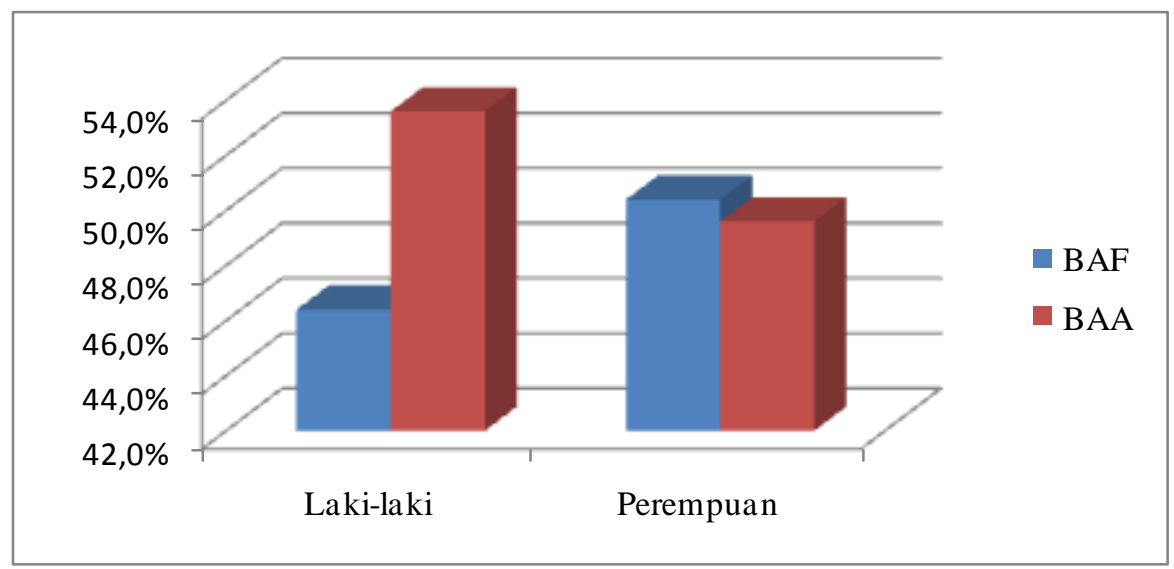

Diagram 3. Pemilihan BAF dan BAA berdasarkan Gender

1. Penggunaan BAF dan BAA interaksi sosial. Persentase rata-rata dalam Interaksi Sosial BAA lebih tinggi dibandingkan BAF.

Penggunaan BAF dan BAA dalam Persentase rata-rata penggunaan BAA interaksi sosial juga sama dengan mencapai $57.0 \%$ sedangkan rata-rata pemilihan BAF dan BAA dalam penggunaan BAF mencapai $43.0 \%$.

\begin{tabular}{|c|c|c|c|c|c|}
\hline \multirow{2}{*}{ No. } & \multirow{2}{*}{ Situasi } & \multicolumn{2}{|c|}{ BAF } & \multicolumn{2}{|c|}{ BAAA } \\
\hline & & $\mathbf{f}$ & $\%$ & $\mathbf{f}$ & $\%$ \\
\hline 1 & إذا كنت في البيت مع عائلتك، أيهما & 7 & $14.0 \%$ & 43 & $86.0 \%$ \\
\hline 2 & عند التحدثا تستخدم ؟ إلى الاصدقاء أو الجيران، & 7 & $14.0 \%$ & 43 & $86.0 \%$ \\
\hline 3 & إذا كنت في جامعتك، أيهما تستخدم؟ & 27 & $54.0 \%$ & 23 & $46.0 \%$ \\
\hline 4 & 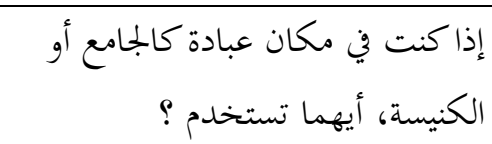 & 37 & $74.0 \%$ & 13 & $26.0 \%$ \\
\hline 5 & ماذا ستستخدم لو كنت في السوق ؟ & 10 & $20.0 \%$ & 40 & $80.0 \%$ \\
\hline 6 & أيهما ستستخدم إذا أردت أن تروي & 5 & $10.0 \%$ & 45 & $90.0 \%$ \\
\hline
\end{tabular}




\begin{tabular}{|c|c|c|c|c|c|}
\hline & نكتة مضحكة ؟ & & & & \\
\hline 7 & ؟ أيهما ستستخدم إذا أردت أن تسرد قصة & 36 & $72.0 \%$ & 14 & $28.0 \%$ \\
\hline 8 & 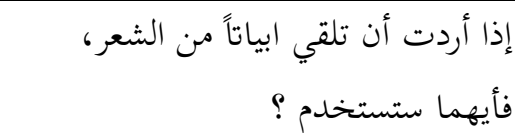 & 43 & $86.0 \%$ & 7 & $14.0 \%$ \\
\hline \multicolumn{2}{|r|}{ Rata-rata } & & $43.0 \%$ & & $\mathbf{5 7 . 0 \%}$ \\
\hline
\end{tabular}

Tabel 7. Penggunaan BAF dan BAA dalam Interaksi Sosial

Penggunaan BAA dan BAF pada situasi 1 yakni penggunaan bahasa Arab ketika berada di rumah dan situasi 2 ketika berbicara dengan teman atau tetangga, memiliki persentase yang sama yaitu $86.0 \%$ untuk penggunaan BAA dan $14.0 \%$ untuk penggunaan BAF. Ini berarti penggunaan BAA pada situasi 1 dan 2 lebih tinggi dibandingkan penggunaan BAF. Alasan yang disebutkan oleh mahasiswa juga sama dengan alasan yang disebutkan pada pemilihan bahasa Arab. Mahasiswa beralasan bahwa BAA adalah bahasa yang simpel (basi>th) sehingga lebih mudah digunakan. Adapun mahasiswa yang memilih BAF pada situasi 1 dan 2 karena BAF adalah bahasa asli dan perlu dijaga keasliannya. Oleh karena itu, mahasiswa memilih BAF untuk berbicara dengan keluarga, tetangga, dan temannya dibandingkan BAA.

Situasi penggunaan bahasa Arab ketika berada di mall/pasar (situasi 5) dan situasi penggunaan bahasa Arab ketika sedang bercanda (situasi 6) juga menunjukkan persentase yang lebih tinggi pada BAA. Persentase penggunaan BAA pada situasi 5 mencapai $80.0 \%$, dan penggunaan BAA pada situasi 6 mencapai $90.0 \%$. Mereka memberikan alasan bahwa BAA adalah bahasa yang mudah dan biasa digunakan dalam kehidupan sehari-hari sehingga ketika berada di pasar akan lebih baik menggunakan BAA dibandingkan BAF. Begitu juga dengan bahasa yang digunakan dalam bercanda, mahasiswa lebih memilih menggunakan BAA dibandingkan BAF karena candaan tersebut akan lebih mengena dan lucu ketika menggunakan BAA sehingga bahasanya juga lebih luwes dan variatif.

Kemudian, pada situasi 3 yakni penggunaan bahasa Arab ketika di tempat kerja (universitas), mahasiswa hampir sama dalam menggunakan BAF dan BAA. Persentase penggunaan BAF mencapai $54.0 \%$ sedangkan persentase penggunaan BAA mencapai $46.0 \%$. Situasi ini berarti mahasiswa banyak yang menggunakan BAF dan juga BAA, dilihat dengan persentase keduanya yang hampir sama.

Berbeda dengan situasi 3, situasi 4 yakni penggunaan bahasa Arab ketika berada di masjid atau tempat ibadah memiliki persentase yang tinggi pada BAF dibandingkan BAA. Persentase penggunaan BAF pada situasi 4 mencapai $74.0 \%$, sedangkan persentase penggunaan BAA mencapai $26.0 \%$. Alasan mahasiswa menggunakan BAF daripada BAA di tempat ibadah karena mereka lebih memahami makna al-Qur'an dengan bahasa al-Quran (BAF), mahasiswa juga menganggap bahwa BAF adalah 
bahasa yang tinggi. Oleh karena itu, BAF lebih baik ketika digunakan di tempat ibadah dibandingkan BAA.

Begitu pula pada situasi 7 dan 8 , penggunaan BAF lebih tinggi dibandingkan BAA. Situasi 7 yakni penggunaan bahasa Arab ketika bercerita/ membacakan sebuah cerita memiliki persentase $72.0 \%$ untuk BAF. Kemudian situasi 8 yakni penggunaan bahasa Arab ketika bersyair/ membacakan sebuah syair memiliki persentase $86.0 \%$ untuk BAF. Alasan yang diutarakan oleh mahasiswa menggunakan $\mathrm{BAF}$ dibandingkan BAA karena bahasa yang digunakan oleh penyair adalah BAF sehingga akan lebih indah jika menggunakan BAF. Kemudian BAF adalah bahasa yang cocok untuk bercerita/membacakan sebuah cerita. Maka dari itu, mahasiswa lebih memilih BAF pada kedua situasi tersebut.

Adapun penggunaan BAF dan BAA dalam interaksi sosial berdasarkan gender berbeda dengan pemilihan BAF dan BAA dalam interaksi sosial.

\begin{tabular}{|l|l|l|l|}
\hline No. & \multicolumn{1}{|c|}{ Gender } & \multicolumn{1}{c|}{ BAF } & \multicolumn{1}{c|}{ BAA } \\
\hline 1. & Laki-laki/ Maskulin & $35.1 \%$ & $64.9 \%$ \\
\hline 2. & Perempuan/ Feminin & $47.0 \%$ & $53.0 \%$ \\
\hline
\end{tabular}

Tabel 8. Penggunaan BAF dan BAA berdasarkan Gender

Penggunaan BAA pada laki-laki dan perempuan sama-sama lebih tinggi daripada penggunaan BAF. Namun, persentase penggunaan BAA oleh lakilaki lebih tinggi dibandingkan perempuan. Persentase penggunaan BAA oleh laki-laki mencapai $64.9 \%$, sedangkan persentase penggunaan BAA oleh perempuan mencapai 53.0
$\%$. Hal tersebut berarti mahasiswa lakilaki cenderung lebih banyak menggunakan BAA daripada mahasiswa perempuan. Sebaliknya, mahasiswa perempuan cenderung lebih banyak menggunakan BAF dibandingkan mahasiswa laki-laki, meskipun tidak begitu signifikan.

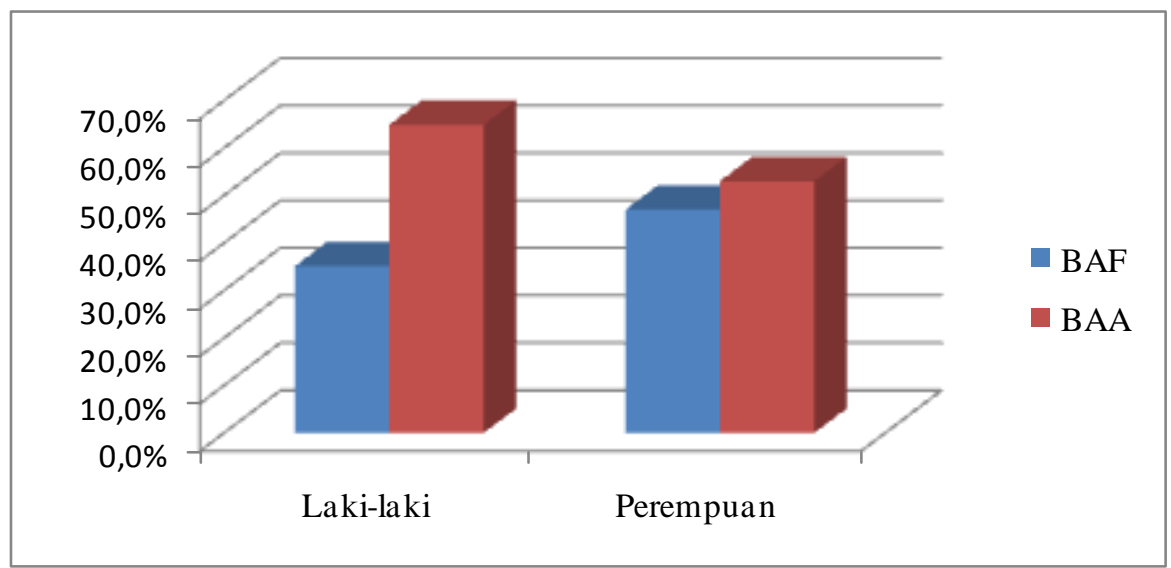

Diagram 4. Penggunaan BAF dan BAA berdasarkan Gender

Berdasarkan penjelasan hasil di pemilihan dan penggunaan bahasa atas, maka dapat disimpulkan bahwa Arab dalam interaksi sosial, mahasiswa 
Universitas Canal Suez Mesir lebih banyak memilih dan menggunakan BAA dibandingkan BAF, dengan ratarata pemilihan dan penggunaan $\mathrm{BAF}$ dan BAA yang telah disebutkan. Dalam interaksi sosial terdapat gender yang ternyata memengaruhi pemilihan dan penggunaan BAF dan BAA. Mahasiswa laki-laki lebih memilih BAA dibandingkan mahasiswa perempuan. Begitu pula dengan penggunaan BAA oleh mahasiswa lakilaki, persentase yang ditunjukkan lebih tinggi dibandingkan mahasiswa perempuan.

3. Pemilihan dan Penggunaan Bahasa Arab dalam Media

Media merupakan salah satu alat yang digunakan oleh mahasiswa untuk mendapatkan informasi dan berkomunikasi. Ranah ini mengacu pada macam-macam tayangan yang ada di media elektronik (tayangan komedi, debat politik, berita, dan tayangan program edukasi) serta ketika mendengarkan lagu. Pada situasisituasi tersebut, bahasa yang lebih digunakan oleh mahasiswa bervariasi tergantung pada tayangan yang dilihat atau ditonton mahasiswa.

Persentase rata-rata pemilihan dan penggunaan BAF dan BAA pada ranah ini hampir sama. Persentase rata-rata pemilihan dan penggunaan $\mathrm{BAF}$ mencapai $50.3 \%$, sedangkan persentase rata-rata pemilihan dan penggunaan BAA mencapai $49.7 \%$.

\begin{tabular}{|c|c|c|c|c|c|}
\hline \multirow{2}{*}{ No. } & \multirow{2}{*}{ Situasi } & \multicolumn{2}{|c|}{ BAF } & \multicolumn{2}{|c|}{ BAA } \\
\hline & & f & $\%$ & $\mathbf{f}$ & $\%$ \\
\hline 1 & ما الذي تفضله عندما تشاهد مسلسل & 16 & $32 \%$ & 34 & $68 \%$ \\
\hline 2 & ما كوميدية الذي تفضله عندما تشاهد مسرحية & 7 & $14 \%$ & 43 & $86 \%$ \\
\hline 3 & إذا إستمعت إلى أي أغنية، أيهما تفضل؟ & 16 & $32 \%$ & 34 & $68 \%$ \\
\hline 4 & 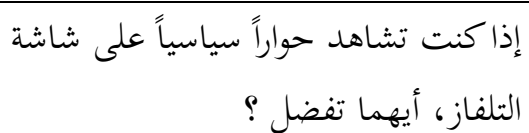 & 38 & $76 \%$ & 12 & $24 \%$ \\
\hline 5 & 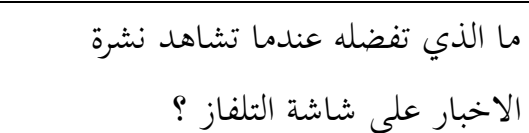 & 38 & $76 \%$ & 12 & $24 \%$ \\
\hline 6 & 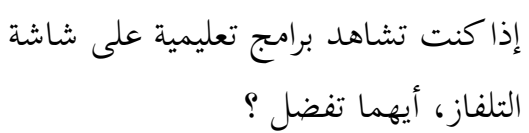 & 36 & $72 \%$ & 14 & $28 \%$ \\
\hline & Rata-rata & & $50.3 \%$ & & $49.7 \%$ \\
\hline
\end{tabular}

Tabel 9. Pemilihan dan Penggunaan BAF dan BAA dalam Media 
Pada situasi 1, 2, dan 3 memiliki persentase yang tinggi pada pemilihan dan penggunaan BAA. Situasi 1 yakni pemilihan dan penggunaan bahasa Arab ketika menonton tayangan televisi memiliki persentase $68.0 \%$ untuk BAA dan $32.0 \%$ untuk BAF. Situasi 2 yakni pemilihan dan penggunaan bahasa Arab ketika menonton tayangan komedi memiliki persentase $86.0 \%$ untuk BAA, dan $14 \%$ untuk BAF. Kemudian pada situasi 3 yakni pemilihan dan penggunaan bahasa Arab ketika mendengarkan sebuah lagu memiliki persentase yang sama dengan situasi 1, yakni $68.0 \%$ untuk BAA dan $32.0 \%$ untuk BAF.

Berbanding terbalik dengan ketiga situasi di atas, persentase situasi 4, 5, dan 6 lebih banyak pada pemilihan dan penggunaan BAF. Situasi 4 yakni pemilihan dan penggunaan bahasa Arab ketika menonton debat politik dan situasi 5 yakni pemilihan dan penggunaan bahasa Arab ketika menonton berita memiliki persentase yang sama pada BAF sebanyak 76\% dan $24 \%$ pada BAA.

Kemudian pada situasi 6 yakni pemilihan dan penggunaan bahasa Arab ketika menonton program edukasi di televisi memiliki persentase sebanyak $72 \%$ untuk BAF dan $28 \%$ untuk BAA.

Alasan lebih banyak pemilihan dan penggunaan $\mathrm{BAF}$ pada ketiga situasi tersebut karena mahasiswa sebagai pemirsa/orang yang menonton tayangan debat, berita, dan program edukasi tersebut merasa lebih paham dan fokus ketika tayangan tersebut disampaikan dengan BAF. Lalu pada tayangan program edukasi, mahasiswa juga merasa dapat menerima pengetahuan/informasi yang disampaikan menggunakan BAF.
Berdasarkan penjabaran tersebut, maka dapat disimpulkan bahwa pemilihan dan penggunaan bahasa Arab pada ranah ini dipengaruhi oleh jenis tayangan yang dihadirkan. Jika tayangan tersebut bersifat serius, maka mahasiswa lebih memilih dan menggunakan BAF dibandingkan BAA. Sebaliknya, jika tayangan tersebut bersifat menghibur seperti komedi dan musik (lagu) mahasiswa lebih memilih dan menggunakan BAA dibandingkan BAF.

\section{Kesimpulan}

Pemilihan dan penggunaan BAF dan BAA pada ranah akademik, interaksi sosial, dan media oleh mahasiswa Universitas Canal Suez Mesir menunjukkan hasil sebagai berikut.

a. Pada ranah akademik, mahasiswa cenderung memilih dan menggunakan BAF dibandingkan BAA. Alasan mahasiswa memilih dan menggunakan BAF karena BAF adalah bahasa al-Qur'an yang terjaga keasliannya, dan juga bahasa yang bagus ( $r a>i$ 'ah). Oleh karena itu, mahasiswa lebih memilih dan menggunakan BAF dibandingkan BAA. Mahasiswa memilih dan menggunakan BAF ketika berada di dalam kelas baik kelas sosial maupun eksak, dan ketika membaca buku atau artikel. Adapun alasan pemilihan dan penggunaan BAA pada ranah akademik karena BAA dianggap lebih mudah dipahami dibandingkan BAF.

b. Pada ranah interaksi sosial, mahasiswa cenderung memilih BAA dibandingkan BAF. 
Alasan mahasiswa memilih dan menggunakan BAA pada ranah interaksi sosial karena BAA adalah bahasa yang mudah digunakan, simpel, dan biasa digunakan. Mahasiswa memilih dan menggunakan BAA ketika berbincang-bicang dengan keluarga, teman-teman, tetangga. Mahasiswa juga memilih dan menggunakan BAA ketika berada di pasar. Adapun, ketika berada di masjid dan universitas, mahasiswa lebih memilih dan menggunakan BAF dibandingkan BAA. Begitu pula, ketika membacakan cerita maupun syair, mahasiswa memilih dan menggunakan BAF.

Pada ranah media, rata-rata pemilihan dan penggunaan BAF lebih besar dibandingkan BAA. Mahasiswa lebih memilih dan menggunakan BAF ketika pada situasi serius,

c. seperti pada tayangan debat politik, berita, dan program edukasi. Pemilihan dan penggunaan BAF pada situasi tersebut dikarenakan mahasiswa merasa lebih serius dan fokus ketika penyampaian tayangan tersebut menggunakan BAF. Kemudian, pada tayangan yang bersifat menghibur seperti komedi dan musik (lagu), mahasiswa lebih memilih dan menggunakan BAA karena mereka menganggap BAA itu mudah dan pesan yang disampaikan lebih mengena kepada penonton. d. Pada ranah akademik, program studi memiliki pengaruh terhadap pemilihan dan penggunaan bahasa Arab. Program studi yang memiliki persentase tertinggi pada pemilihan dan penggunaan BAF pada ranah akademik adalah program studi Matematika, Kimia, Perhotelan, Bahasa Arab, dan Sejarah.

e. Pada ranah interaksi sosial, gender memiliki pengaruh terhadap pemilihan dan penggunaan bahasa Arab oleh mahasiswa Universitas Canal Suez Mesir. Mahasiswa lakilaki memiliki persentase yang lebih tinggi dalam pemilihan dan penggunaan BAA dibandingkan mahasiswa perempuan. Pada pemilihan bahasa Arab, mahasiswa perempuan lebih memilih menggunakan BAF sedangkan pada penggunaan bahasa Arab, mahasiswa perempuan lebih memilih menggunakan BAA dibandingkan BAF dengan persentase yang lebih kecil dibandingkan persentase penggunaan BAA mahasiswa laki-laki.

\section{Daftar Pustaka}

Al-Marani, Yahya Mohammed Ali dan Azimah Binti Sazalle. 2010. Polite Request Strategies by Male Speakers of Yemeni Arabic in Male-Male Interction and MaleFemale Interaction. The International Journal of Language Society and Culture. Universiti Sains Malaysia 
Azhar, Iqbal Nurul., dkk. 2011. Lambert, W.E. 1967. A Social Sosiolinguistik Teori dan Praktik. Psychology of Bilingualism. Surabaya: Lima-lima Jaya Journal of Social Issues 23: 91-109

Blum-Kulka, S. 1982. Learning how to say what you mean in second language: a study of speech Act performance of learners of hebrew as a second language. Applied Linguistics, 3

Chaer, Abdul dan Leonie Agustina. 2008. Sosiolinguistik Perkenalan Awal. Jakarta: PT Rineka Cipta

Ciscel, dkk. 2000. Language Attitude and Identity in the European Republics of the Former Soviet Union. Texas Linguistic Forum 44: 49

Dingding, Haerudin. 2003. Peranan Sikap Berbahasa Mahasiswa terhadap

Kemampuan Menulis. Jurnal. Bandung: FPBS UPI. Vol. 3 No. 5

Fasold, Ralph. 2001. The Sociolinguistics of Society. New York: Basil Blackwell

Husaini, Usman dan Purnomo Setiady Akbar. 2014. Metodologi Penelitian Sosial. Jakarta: PT. Bumi Aksara

Kesuma, Tri Mastoyo Jati. 2007. Pengantar (Metode) Penelitian Bahasa. Yogyakarta: Carasvatibooks

Mizher, Rabab A. dan Fawwaz AlAbed Al-Haq. 2014. Attitudes towards Using Standard Arabic among Academic Staff at Balqa Applied University/Center in Jordan: A Sociolinguistic Study. Jordan: International Journal of English Linguistics. Vol. 4 No. 1

Monks, dkk. 1992. Psikologi Perkembangan. Yogyakarta: Universitas Gadjah Mada

Murad, Mohammed Kamil. 2007. Language Attitudes of Iraqi Native Speakers of Arabic : A Sosiolinguistic Investigation. Faculty of Graduate School of the University of Kansas

Pateda, Mansoer. 1990. Sosiolingustik. Bandung: Angkasa

Rokhman, $\quad$ Fathur. 2013. Sosiolinguistik. Yogyakarta: Graha Ilmu

Sudaryanto. 1993. Metode dan Aneka Teknik Analisis Bahasa. Yogyakarta: Duta Wacana University Press.

Tohe, Achmad. 2005. Bahasa Arab Fuscha dan Amiyah serta Problematikanya. Malang: Jurnal Bahasa dan Seni, Tahun 33, Nomor 2, Agustus 2005 